\title{
Peningkatan Pemahaman Guru Mengenai Pengamanan Data Ajar Melalui Pelatihan Online di SMPN I Karangwelas
}

\author{
Ranggi Praharaningtyas Aji*1, M. Awiet W.P², Argian Dwi Pritama3 ${ }^{3}$, Ika Ayu Pratiwi ${ }^{4}$, \\ Resti Nur Azizah ${ }^{5}$ \\ ranggi.p.aji@amikompurwokerto.ac.id ${ }^{* 1}$ \\ 1,2,3,4,5 Sistem Informasi, Fakultas Ilmu Komputer, Universitas Amikom Purwokerto
}

Received: 28 Mei 2021

Accepted: 10 Juli $2021 \quad$ Online Published: 31 Juli 2021

DOI: 10.29408/ab.v2i1.3549

URL: http://dx.doi.org/10.29408/ab.v2i1.3549

\begin{abstract}
Abstrak: Pentingnya mengamankan data menjadi hal yang diabaikan oleh para guru. Selain itu ketidakmampuan mereka mengamankan data juga menjadi hal pendukung terjadinya kegagalan dalam melakukan pengamanan data. membiarkan akses ke komputer pribadinya diketahui dan hilangnya data akibat virus menjadi hal yang sering dialami oleh guru SMPN 1 Karanglewas. Untuk itu dibuatlah pelatihan yang dikemas dalam webinar pengamanan data ajar. Tujuan kegiatan ini adalah menumbuhkan pemahaman dan kesadaran para guru dalam mengamankan data ajar yang mereka miliki. Pelaksanaan kegiatan ini menggunakan teknologi google meet yang dapat juga diakses melalui kanal youtube secara langsung. Hasil yang didapat adalah meningkatnya pemahaman para guru dilihat dari selisih hasil post-test dan pre-test yang mencapai angka 40-80\%. Selain itu juga tanggapan positif para guru peserta webinar yang menyatakan dengan $56 \%$ peserta menyatakan baik dan $30 \%$ cukup, dan 24\% sangat baik. Kegiatan selanjutnya yang diharapkan akan dilaksanakan berupa pelatihan pembuatan kelas secara live dan pembuatan bahan ajar interaktif
\end{abstract}

Kata Kunci: Keamanan Data; Guru; Kesadaran Pengamanan Data

\begin{abstract}
The importance of securing data is something that most Indonesian teachers ignore. In addition, their inability to secure data is also a factor supporting the failure to secure data. Allowing access to their personal computers to be known and the loss of data due to viruses is often experienced by teachers at SMPN 1 Karanglewas. For this reason, training is made that is packaged in a teaching data security webinar. This activity aims to grow the understanding and awareness of teachers in securing the teaching data they have. The implementation of this activity uses Google Meet technology, which can be accessed directly through the YouTube channel. The results obtained are the increasing understanding of the teachers seen from the difference in the results of the post-test and pre-test, which reaches 40-80\%. In addition, there were also positive responses from the teachers participating in the webinar, which stated that $56 \%$ of the participants stated that it was good and $30 \%$ was sufficient, and $24 \%$ was excellent. The next activity that is expected to be carried out is live class making training and the manufacture of interactive teaching materials.
\end{abstract}

Keyword: Data Security; Teachers; Data Security Awareness 
Aji, R. P., Prasetyo, M. A. W., Pritama, A. D., Pratiwi, I. A., \& Aziz, R. N. (2021). Peningkatan pemahaman guru tentang pengamanan data ajar melalui pelatihan online di SMPN I Karangwelas. ABSYARA: Jurnal Pengabdian Pada Masyarakat, $2(1)$, 62-71. doi:10.29408/ab.v2i1.3549

\section{PENDAHULUAN}

Pengamanan data tidak hanya berlaku untuk data penting di suatu server perusahaan besar. Pengamanan data juga perlu diterapkan untuk segala hal yang berkaitan dengan teknologi komputer secara umum. Terlebih lagi Indonesia merupakan negara dengan risiko serangan (Triandi, 2019). Guru di SMPN 1 Karanglewas yang membiarkan akses ke komputer pribadinya diketahui oleh orang banyak atau bahkan memberitahukan informasi yang penting milik dirinya kepada orang lain. Hal ini masih dipandang hal yang sepele dan bahkan dianggap hal yang wajar (Pane, 2021). Hal tersebut pastinya sangat membahayakan karena akses yang diberikan artinya tidak lagi ada privasi yang dimiliki. Menurut Yuwinanto, (2015) penggunaan perangkat sistem informasi yang terhubung ke jaringan atau online memunculkan isu privasi dan menurutnya ada beberapa langkah yang bisa digunakan untuk menjaga privasi itu yaitu memberikan pengguna mekanisme pengontrolan khususnya pada data atau informasi yang dimiliki.

Selain permasalahan yang sudah disebutkan masih ada banyak ancaman yang mungkin terjadi pada data yang dimiliki terlebih jika data tersebut diletakkan pada perangkat yang terhubung ke jaringan internet. Putri, dkk (2020) memberikan beberapa contoh ancaman data antara lain malware dan virus. Banyak guru di SMPN 1 Karanglewas yang sering mengeluh terjadinya kehilangan data yang disebabkan virus akibat penggunaan flashdisk yang bergantiganti. Hal ini terjadi pada saat para guru harus mengumpulkan nilai atau pada waktu penting lainnya. Hal ini jelas mengganggu pelayanan guru-guru tersebut kepada siswa dan orang tua siswa karena keterlambatan pelaporan nilai.

Solusi yang ditawarkan bagi mitra SMPN 1 Karanglewas adalah memberikan pelatihan bagi guru untuk dapat meningkatkan pemahaman dan kesadaran atas pentingnya menjaga keamanan data yang dimiliki. selain menumbuhkan pemahaman dan kesadaran akan pentingnya menjaga keamanan, guru yang mengikuti pelatihan juga akan diberikan tes tertulis yang dapat dijadikan acuan seberapa tinggi tingkat pemahaman sebelum mengikuti pelatihan dan sesudah pelatihan. Kegiatan serupa juga dilaksanakan oleh Ulfah, dkk. (2021) dimana dilakukan pelatihan secara online untuk meningkatkan kesadaran siswa. Pelatihan ini dibuat dalam bentuk webinar. Webinar ini dibuat untuk memberikan pengarahan bagaimana sebaiknya guru-guru dalam mengamankan data penting yang mereka miliki. Bentuk pelatihan secara online seperti ini dirasa efektif karena semua peserta dapat mengikuti acara dari mana saja (Samsuri, dkk., 2020).

kegiatan ini penting karena tidak semua guru SMP mengerti bahaya dari ancaman didunia komputer. Hasil yang ingin dicapai adalah meningkatnya kesadaran dan pemahaman akan pentingnya mengamankan data yang dimiliki oleh para guru SMP. Pentingya membangun kewaspadaan dalam beraktivitas di internet membuat kita perlu untuk mengetahui apa saja halhal yang bisa dan tidak bisa dilakukan (Islamy, dkk., 2018).

\section{METODE PELAKSANAAN}

\section{Waktu dan Lokasi}

Pelaksanaan kegiatan pengabdian masyarakat ini dilaksanakan pada tanggal 6 Maret 2021 pukul 10.00- 12.00. Lokasi pelaksanaan dilakukan di studio milik AMPU TV Universitas Amikom Purwokerto, dan peserta mengakses secara daring dengan bantuan google meet. 
Aji, R. P., Prasetyo, M. A. W., Pritama, A. D., Pratiwi, I. A., \& Aziz, R. N. (2021). Peningkatan pemahaman guru tentang pengamanan data ajar melalui pelatihan online di SMPN I Karangwelas. ABSYARA: Jurnal Pengabdian Pada Masyarakat, $2(1)$, 62-71. doi:10.29408/ab.v2i1.3549

\section{Prosedur pelaksanaan}

Kegiatan pengabdian masyarakat yang dilaksanakan oleh penulis dan bekerjasama dengan SMPN 1 Karanglewas ini diadakan dalam bentuk webinar. Acara webinar ini dilaksanakan dalam beberapa bagian acara.

1. Pertama dilakukan pre-test. Tujuan dari pre-test adalah menilai kondisi saat ini pemahaman guru peserta webinar.

2. Dilanjutkan dengan pemberian materi oleh pemateri.

3. Setelah materi disampaikan dilanjutkan dengan melakukan tanya jawab dan diskusi antara peserta dan narasumber.

4. Tahap akhir dari acara webinar pelatihan ini adalah melakukan posttest untuk menilai pemahaman guru setelah mengikuti webinar pelatihan.

Peserta pada kegiatan webinar ini adalah guru SMPN 1 Karanglewas . Berdasarkan data daftar hadir yang diberikan kepada para peserta terdapat 20 orang yang mengisi daftar hadir tersebut. Dalam pelaksanaan pre-test dan posttest dilaksanakan dengan menggunakan google form, dan dinilai secara langsung oleh sistem. Pelaksanan kegiatan webinar pelatihan pengamanan data ajar ini melibatkan 3 dosen dan 2 mahasiswa dari prodi sistem informasi, Universitas Amikom Purwokerto

\section{HASIL DAN PEMBAHASAN HASIL}

Susunan acara webinar pelatihan pengamanan data ajar adalah sebagai berikut. (1) Pembukaan, (2) Sambutan kepala sekolah, (3) Pre-test, (4) Pemaparan materi, (5) Tanya Jawab, (6) Posttest, (7) Penutup. Rincian kegiatan yang telah dilaksanakan adalah sebagai berikut :

\section{Pre-test}

Hasil pre-test dapat dilihat pada Tabel 1. Hasil pre-test menunjukkan pengetahuan umum para peserta dalam mengamankan data yang dimiliki. dari data tersebut juga dapat kita kaji bahwa para peserta masih merasa Untuk menguraikan hasil pelaksanaan pengabdian kepada masyarakat, skor paling tinggi adalah 60 point dan hanya didapatkan oleh 3 orang peserta saja. Dan masih ada 10 peserta yang poinnya kurang dari rata-rata. Dari data ini dapat disimpulkan bahwa pengetahuan para peserta mengenai pentingnya menjaga data masih sangat kurang.

Tabel 1. Hasil Pre-test

\begin{tabular}{clcc}
\hline No. & Nama & Kode Peserta & Hasil Pre-test \\
\hline 1 & AJI KUSMANTO, S.Pd., M.Hum & WPD01 & $40 / 100$ \\
2 & Ari Driyaningsih, S.Pd.,M.Pd. & WPD02 & $60 / 100$ \\
3 & Cristina Soeharjani,S.Pd & WPD03 & $30 / 100$ \\
4 & Desi Rina Purkantini, S.P & WPD04 & $20 / 100$ \\
5 & Dian Putri Rachmadhani, S.Pd & WPD05 & $20 / 100$ \\
6 & Diar Lestarini, S.Pd. & WPD06 & $20 / 100$ \\
7 & Dimas Aji Prasetyo & WPD07 & $60 / 100$ \\
\hline
\end{tabular}


Aji, R. P., Prasetyo, M. A. W., Pritama, A. D., Pratiwi, I. A., \& Aziz, R. N. (2021). Peningkatan pemahaman guru tentang pengamanan data ajar melalui pelatihan online di SMPN I Karangwelas. ABSYARA: Jurnal Pengabdian Pada Masyarakat, $2(1)$, 62-71. doi:10.29408/ab.v2i1.3549

\begin{tabular}{clcc}
\hline 8 & Fajar Edi Muwwafiq, S.Pd. & WPD08 & $30 / 100$ \\
9 & INTAN PERMATASARI & WPD09 & $40 / 100$ \\
10 & Kati Nurasih, S.TP & WPD10 & $60 / 100$ \\
11 & Laely Mardhiyani, S.Pd & WPD11 & $20 / 100$ \\
12 & Maria Engelina S, S.Pd & WPD12 & $30 / 100$ \\
13 & Ngishmatulloh, S.Pd.I & WPD13 & $40 / 100$ \\
14 & Ninik Murtiatun, A.Ma.Pust & WPD14 & $40 / 100$ \\
15 & Nining Supriyatin,S.Pd & WPD15 & $40 / 100$ \\
16 & Ragil Pamungkas Siwi, S.Pd & WPD16 & $30 / 100$ \\
17 & SITI NURYANTI, S.Pd & WPD17 & $50 / 100$ \\
18 & Suryawati & WPD18 & $30 / 100$ \\
19 & Waliyem, S. Pd. & WPD19 & $30 / 100$ \\
20 & Wini Widiastuti, S.Pd & WPD20 & $30 / 100$ \\
\hline & \multicolumn{2}{c}{ Rata- rata } & $\mathbf{3 6 / 1 0 0}$ \\
\hline
\end{tabular}

2. Pemberian Materi

Pembicara pada pelatihan pengamanan data ajar adalah bapak Ranggi Praharaningtyas Aji. Materi yang disampaikan pada webinar pelatihan pengamanan data ajar ini merupakan sub materi dari mata kuliah Keamanan Sistem Informasi yang ada pada prodi sistem informasi universitas Amikom Purwokerto. Pembicara pada kegiatan webinar pelatihan pengamanan data ajar ini

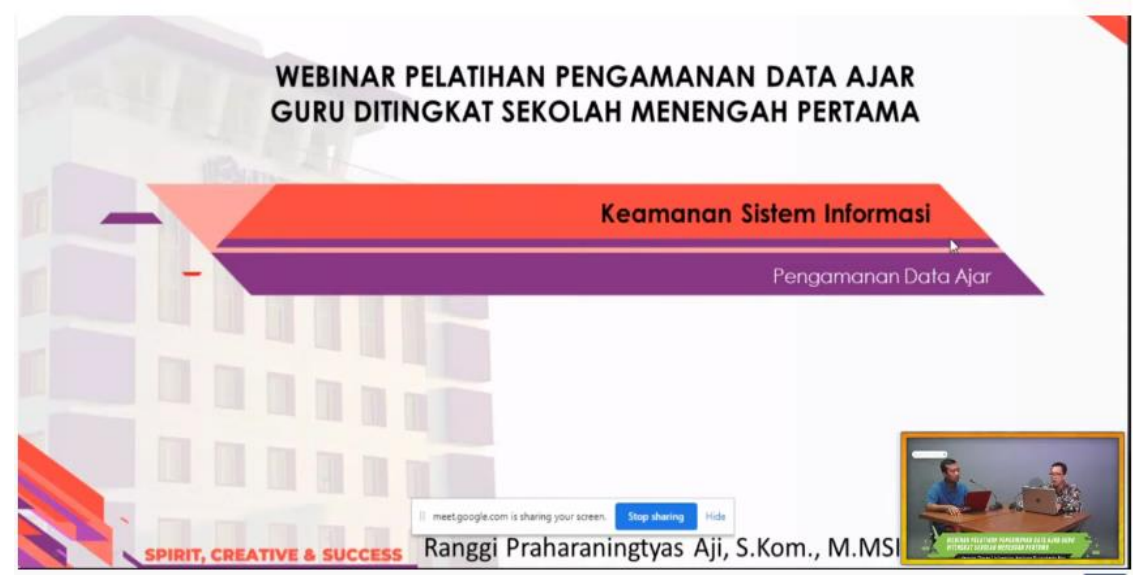

Gambar 1. Pembukaan materi

Gambar 1 memperlihatkan materi kajian pada pengabdian masyarakat ini berfokus pada mata kuliah keamanan sistem informasi. adapun inti materi yang disampaikan kepada para peserta meliputi: (1) mengapa kita perlu mengamankan data kita, materi ini mengantarkan guru-guru untuk mengetahui apa saja dan penyebab mengapa data itu perlu diamankan Bahrudin \& Firmansyah (2018) menyatakan bahwa langkah penting dalam perencanaan keamanan adalah memahami aset yang diamankan termasuk didalamnya data; (2) ancaman 
yang sering dialami oleh para peserta, dimana ancaman yang dapat menimpa data kita adalah dari berbagai sumber (Izatri, dkk., 2020); (3) siapa yang akan bertanggung jawab apabila terjadi ancaman, dan terakhir (4) bagaimana cara kita dalam mengamankan. Pada penyampaiananya sumber acuan pengamanan yang diberikan berdasarkan dari kontrol ISO 27002. Kontrol ISO 27002 merupakan kontrol dan pedoman yang dapat digunakan untuk mengamankan ancaman yang terjadi (Yustanti, dkk., 2018). Seluruh inti materi diperlihatkan pada Gambar 2.

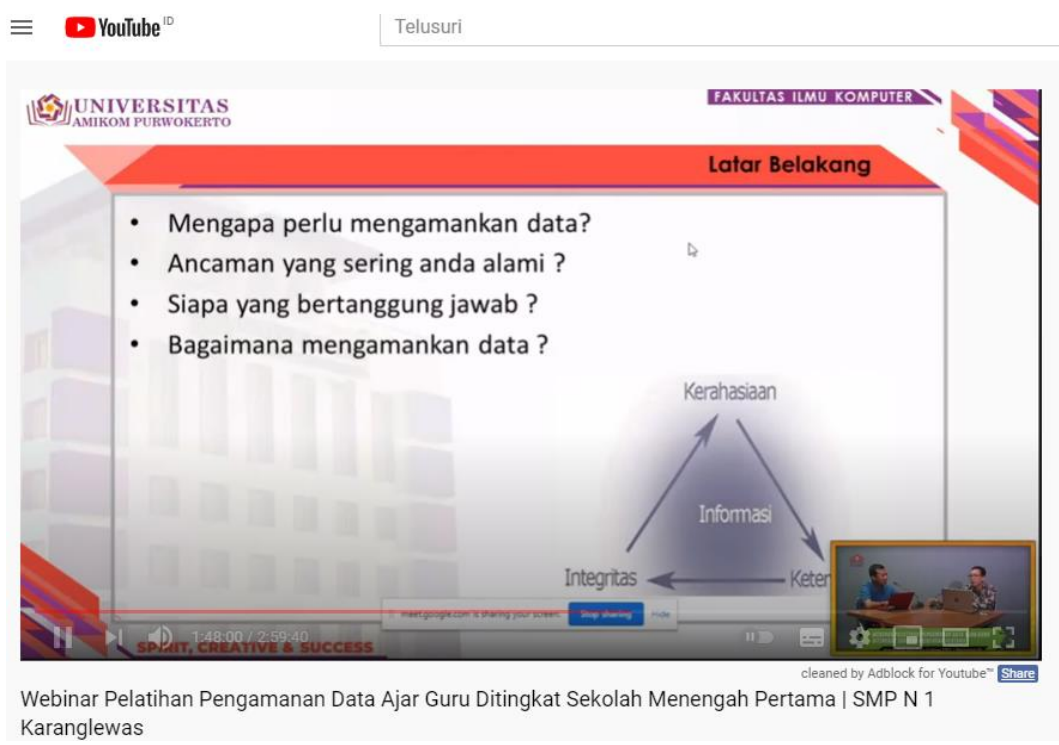

Gambar 2. Inti materi

Pertama-tama peserta diarahkan untuk melakukan identifikasi atas aset yang dimiliki. para peserta diminta mengisi angket perihal aset yang dimiliki. selanjutnya dibahas secara bersama-sama untuk mendapatkan pemahaman mana aset penting dan mana yang sifatnya aset penunjang. Pada sesi berikutnya para peserta dijelaskan ancaman yang dapat menyerang atau membahayakan aset penting yang dimiliki para peserta. Selain itu para peserta juga diberikan angket yang berisi ancaman yang pernah dihadapi. Hasil pengisian angket ini selanjutnya dibahas agar peserta memahami hubungan antara aset yang dimiliki dengan ancaman yang pernah atau akan dihadapi.

Berikutnya peserta diberikan informasi mengenai tanggung jawab pribadi dan instansi atas ancaman atas aset yang dimiliki para peserta. Hal ini perlu disampaikan karena dari hasil angket yang dibagikan para peserta masih menganggap bahwa semua ancaman yang menyerang aset pentingnya merupakan tanggung jawab instansi karena kejadian ancaman itu berlangsung diinstansi. Terakhir para peserta diberikan informasi bagaiman cara mengatasi ancaman yang mereka alami berdasarkan standar ISO 27002 dan diberikan arahan langsung implementasinya oleh pembicara.

\section{Tanya jawab}

Kegiatan selanjutnya adalah sesi tanya jawab. Peserta dipersilahkan untuk bertanya melalui chat pada google meet ataupun secara langsung dan pertanyaaan para peserta akan dijawab oleh narasumber dan moderator. Sesi tanya jawab berdurasi selama 30 menit. Peserta 
Aji, R. P., Prasetyo, M. A. W., Pritama, A. D., Pratiwi, I. A., \& Aziz, R. N. (2021). Peningkatan pemahaman guru tentang pengamanan data ajar melalui pelatihan online di SMPN I Karangwelas. ABSYARA: Jurnal Pengabdian Pada Masyarakat, 2(1), 62-71. doi:10.29408/ab.v2i1.3549

diberikan kesempatan bertanya sebelum dilanjutkan ke sesi post-test. Kondisi saat tanya jawab terlihat pada gambar 3 .

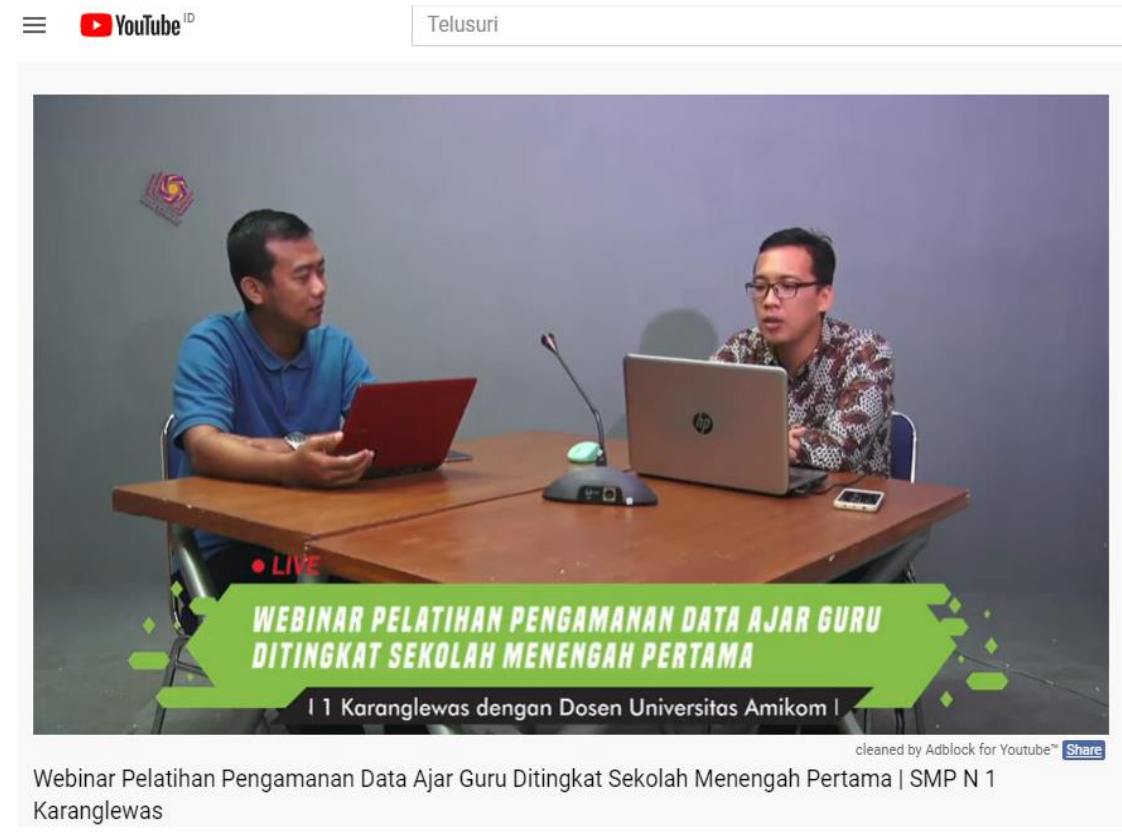

Gambar 3. Sesi tanya jawab

\section{Post-test}

Hasil post-test diperlihatkan pada Gambar 4. Nilai rata-rata yang dari hasil post-test adalah 88 point. Peserta yang mendapat nilai lebih tinggi dari nilai rata-rata ada 12 orang sedangkan 8 sisanya masih mendapatkan nilai kurang dari nilai rata-rata. Para peserta juga diberi kesempatan untuk menjawab post-test maksimal 5 kali percobaan dan rata-rata peserta menjawab sebanyak 3 kali untuk mendapat nilai maksimal. Nilai paling tinggi untuk post-test adalah 100 point, dan nilai paling rendah adalah 70 point. 
Aji, R. P., Prasetyo, M. A. W., Pritama, A. D., Pratiwi, I. A., \& Aziz, R. N. (2021). Peningkatan pemahaman guru tentang pengamanan data ajar melalui pelatihan online di SMPN I Karangwelas. ABSYARA: Jurnal Pengabdian Pada Masyarakat, 2(1), 62-71. doi:10.29408/ab.v2i1.3549

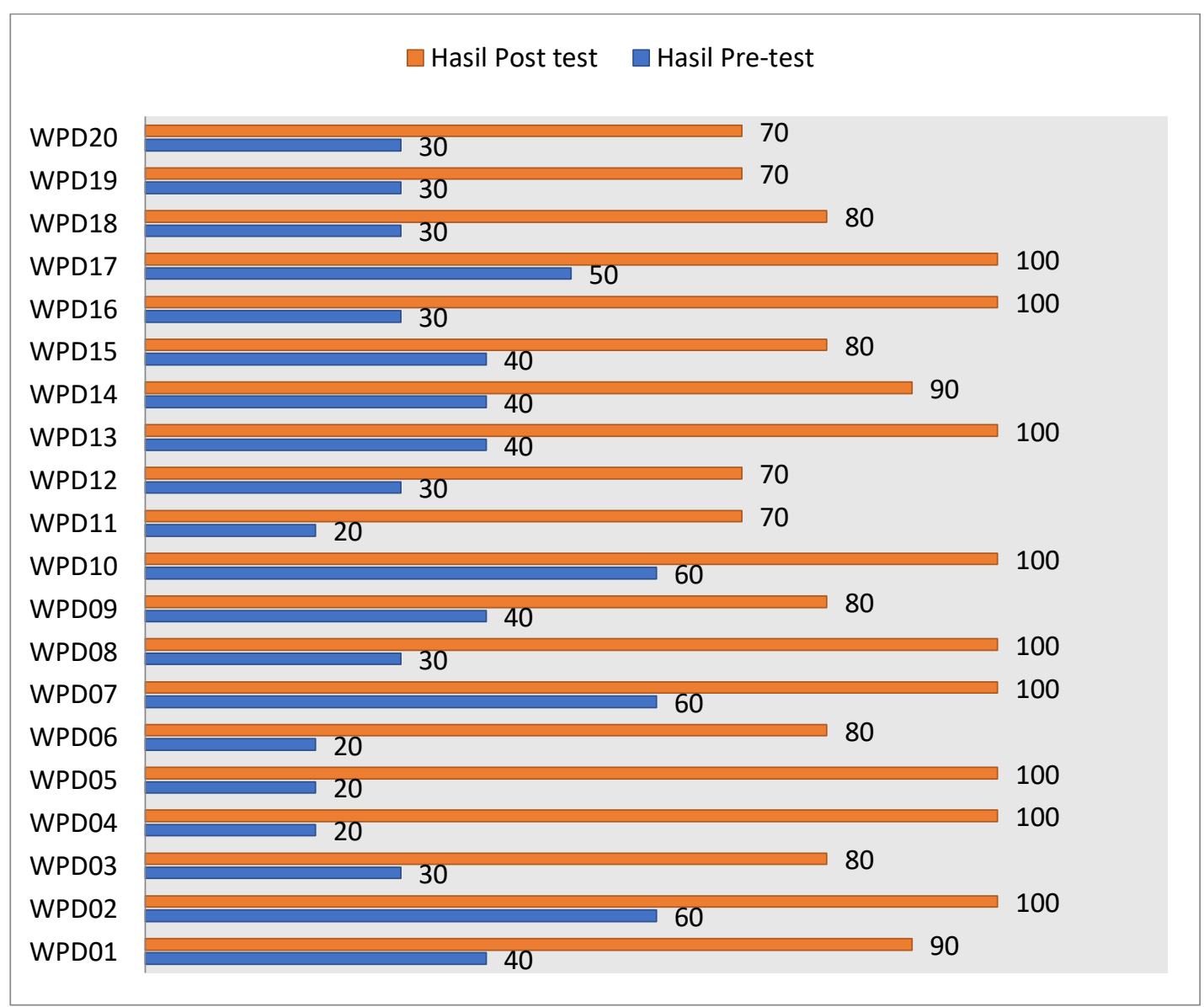

Gambar 4. Hasil Post-test

Secara visual gambaran pengaruh dari webinar ini diperlihatkan pada Gambar 5.

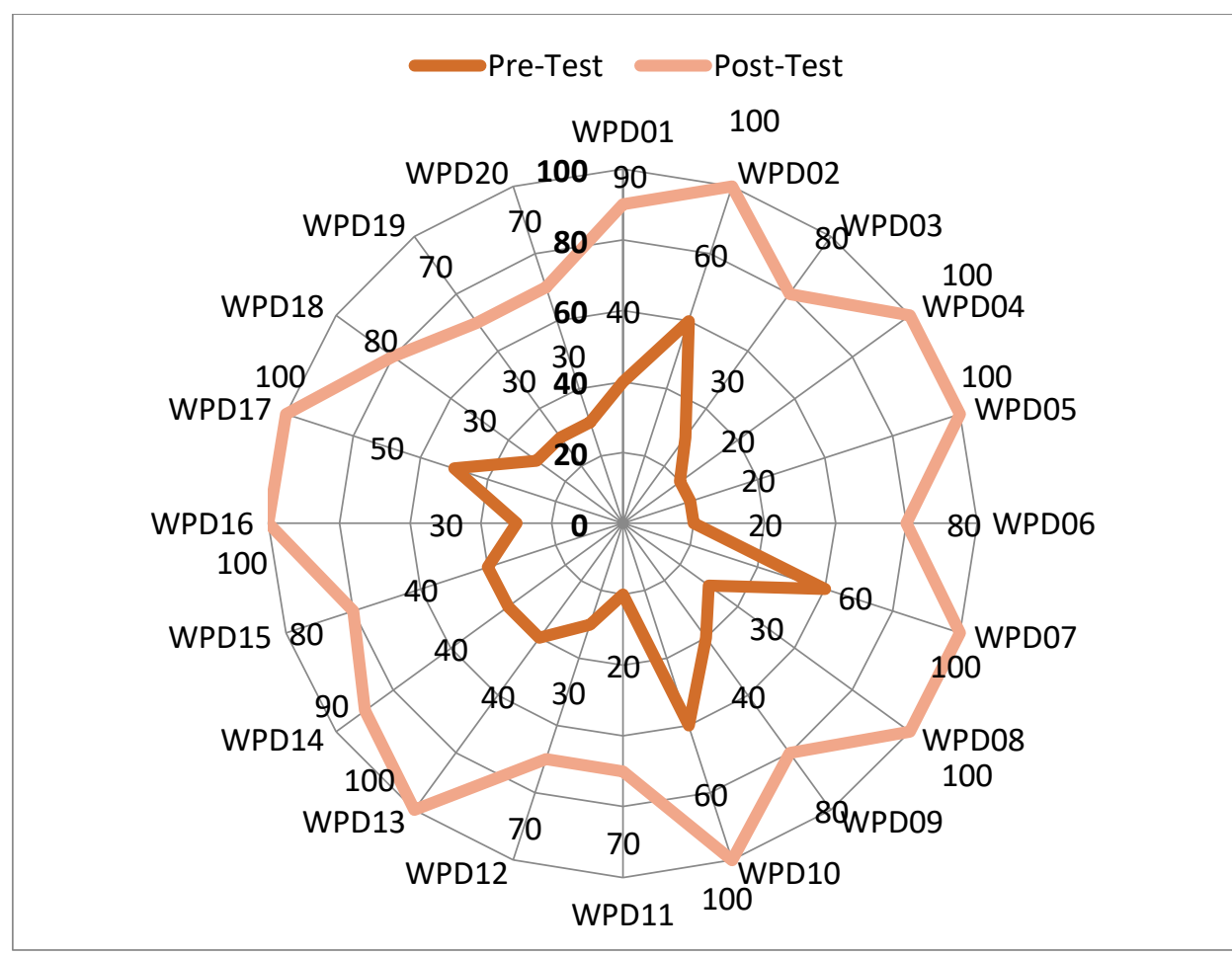


Aji, R. P., Prasetyo, M. A. W., Pritama, A. D., Pratiwi, I. A., \& Aziz, R. N. (2021). Peningkatan pemahaman guru tentang pengamanan data ajar melalui pelatihan online di SMPN I Karangwelas. ABSYARA: Jurnal Pengabdian Pada Masyarakat, $2(1), 62-71$. doi:10.29408/ab.v2i1.3549

Gambar 5. Gap pengetahuan peserta

5. Tanggapan Peserta

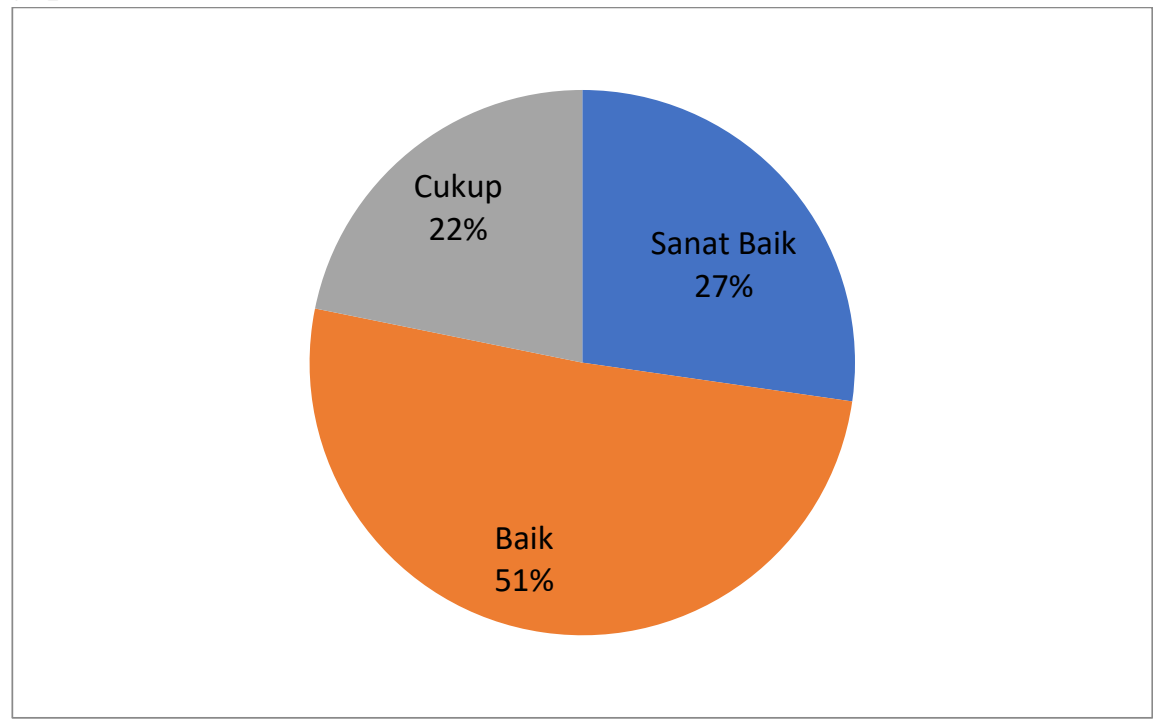

Gambar 6. Tanggapan Peserta

Permintaan para peserta untuk kegiatan berikutnya dapat terlihat pada Gambar 7.

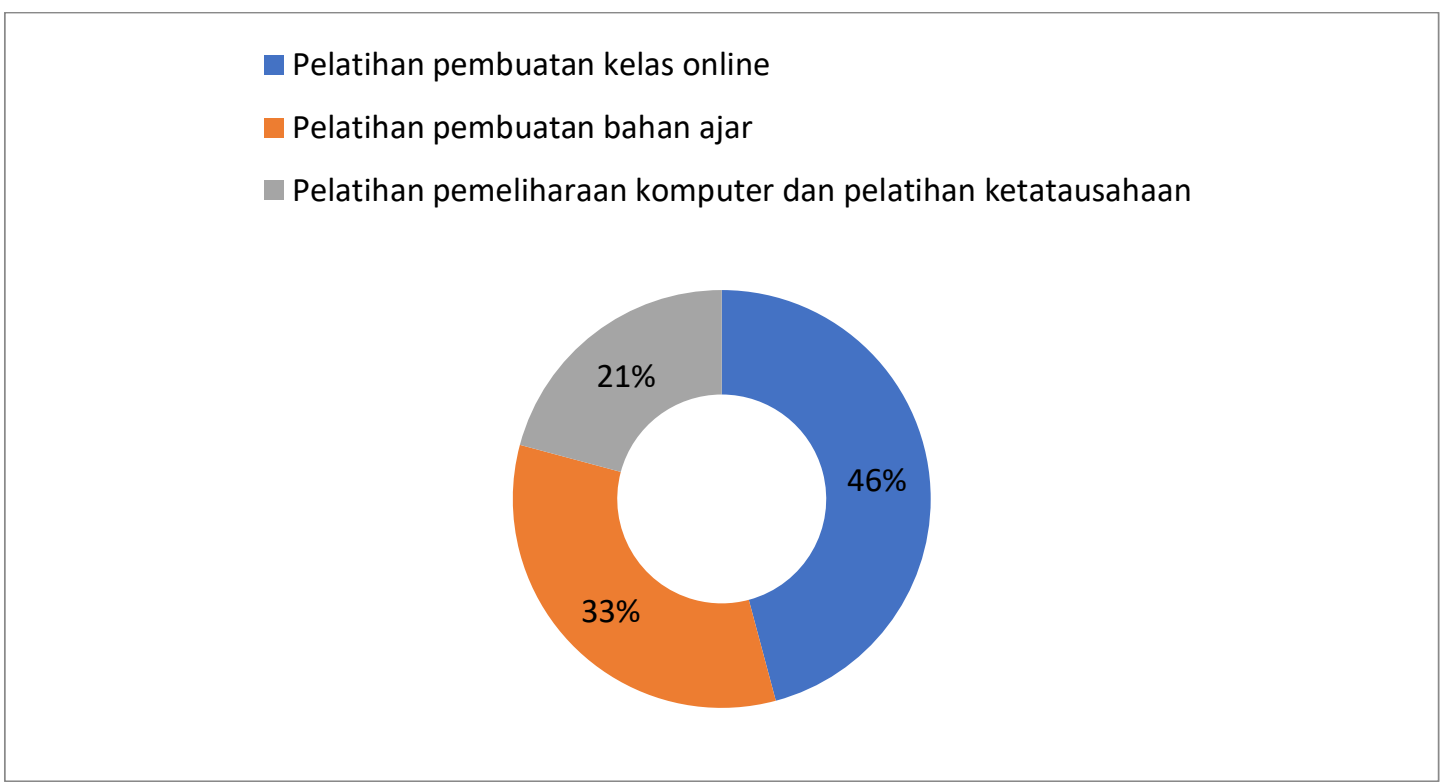

Gambar 7. Kegiatan selanjutnya

\section{PEMBAHASAN}

Berdasarkan hasil post-test diperoleh data gap berupa perbedaan antara nilai yang didapat peserta saat mengikuti pre-test dan post-test. Rata-rata nilai gap adalah 52, artinya ada kenaikan pengetahuan dari peserta sebelum mengikuti kegiatan webinar dibandingkan dengan setelah mengikuti kegiatan webinar. Nilai gap paling kecil peserta adalah 40 dan nilai gap paling besar adalah 80. Berdasarkan nilai gap yang diperoleh dapat diartikan kegiatan webinar ini memberikan efek hingga 40\%-80\% kepada para peserta khususnya pada pengetahuan 
Aji, R. P., Prasetyo, M. A. W., Pritama, A. D., Pratiwi, I. A., \& Aziz, R. N. (2021). Peningkatan pemahaman guru tentang pengamanan data ajar melalui pelatihan online di SMPN I Karangwelas. ABSYARA: Jurnal Pengabdian Pada Masyarakat, $2(1), 62-71$. doi:10.29408/ab.v2i1.3549

peserta terhadap kesadaran menjaga keamanan data. Hal ini sejalan dengan hasil pengabdian yang dilakukan Indrayani (2020), bahwa dengan adanya pelatihan pengamanan data mampu meningkatkan pengetahuan dan kesadaran akan keaman data.

Tanggapan peserta yang mengikuti webinar ini dengan baik dan aktif bertanya pada narasumber. Peserta juga menganggap acara ini berjalan dengan lancar dengan $56 \%$ peserta menyatakan baik dan $30 \%$ cukup, dan $24 \%$ sangat baik. Hasil tanggapan peserta terlihat pada Gambar 6. Para peserta juga memberikan beberapa saran untuk acara selanjutnya antara lain 55\% meminta untuk diberikan pelatihan pembuatan kelas secara live, 40\% meminta untuk dilakukan pelatihan pembuatan bahan ajar interaktif, dan $25 \%$ meminta untuk diberikan pelatihan pemeliharaan komputer dan pelatihan ketatausahaan

\section{SIMPULAN}

Dengan dilaksanakannya kegiatan pengabdian masyarakat berupa webinar pelatihan pengamanan data ajar ini memberikan dampak yang cukup besar pada para pesertanya. Hal ini dibuktikan dengan nilai dampak yang dihasilkan antara 40-80\%. Dari hasil ini diharapkan para guru lebih sadar akan pentingya menjaga keamanan data. Selain itu diharapkan menumbuhkan rasa tanggung jawab untuk mengamankan data pada diri masing-masing peserta

\section{PERNYATAAN PENULIS}

Artikel ini merupakan hasil karya sendiri yang belum pernah dipublikasikan baik secara keseluruhan maupun sebahagian, dalam bentuk jurnal, working paper atau bentuk lain yang dipublikasikan secara umum. Karya ilmiah ini sepenuhnya merupakan karya intelektual dan seluruh sumber yang menjadi rujukan dalam karya ilmiah ini telah sebutkan sesuai kaidah akademik yang berlaku umum, termasuk para pihak yang telah memberikan kontribusi pemikiran pada isi, kecuali yang menyangkut ekspresi kalimat dan disain penulisan.

\section{DAFTAR PUSTAKA}

Bahrudin, M., \& Firmansyah, F. (2018). Manajemen keamanan informasi di perpustakaan menggunakan Framework SNI ISO/IEC 27001. Media Pustakawan, 25(1), 43-50.

Indrayani, R. (2020). Pelatihan pengamanan data cyberspace untuk siswa sekolah lanjutan tingkat atas. Muria Jurnal Layanan Masyarakat, 2(1).

Islamy, I. T., Agatha, S. T., Ameron, R., Fuad, B. H., Evan, E., \& Rakhmawati, N. A. (2018). Pentingnya memahami penerapan privasi di era teknologi informasi. Jurnal Teknologi Informasi dan Pendidikan, 11(2), 21-28.

Izatri, D. I., Rohmah, N. I., \& Dewi, R. S. (2020). Identifikasi risiko pada perpustakaan daerah Gresik dengan NIST SP 800-30. JURIKOM (Jurnal Riset Komputer), 7(1), 50-55. https://doi.org/10.30865/jurikom.v7i1.1756

Pane, C. G. G. (2021). Edukasi kepada siswa sma negeri 1 mimika untuk mengatasi ancaman media online pada data pribadi. KONSTELASI: Konvergensi Teknologi dan Sistem Informasi, 1(2), 412-418.

Putri, N. I., Komalasari, R., \& Munawar, Z. (2020). Pentingnya keamanan data dalam intelijen 
Aji, R. P., Prasetyo, M. A. W., Pritama, A. D., Pratiwi, I. A., \& Aziz, R. N. (2021). Peningkatan pemahaman guru tentang pengamanan data ajar melalui pelatihan online di SMPN I Karangwelas. ABSYARA: Jurnal Pengabdian Pada Masyarakat, $2(1), 62-71$. doi:10.29408/ab.v2i1.3549

bisnis. J-SIKA| Jurnal Sistem Informasi Karya Anak Bangsa, 2(02), 41-48.

Samsuri, T., Muliadi, A., Muhali, M., Asy'ari, M., Prayogi, S., \& Hunaepi, H. (2020). Pelatihan desain media interaktif pada pembelajaran daring bagi dosen pendidikan biologi. ABSYARA: Jurnal Pengabdian Pada Masyarakat, 1(2), 64-69. https://doi.org/10.29408/ab.v1i2.2745

Triandi, B. (2019). Keamanan informasi secara aksiologi dalam menghadapi era revolusi industri 4.0. JURIKOM (Jurnal Riset Komputer), 6(5), 477-483.

Ulfah, A. N., Lizarti, N., Anam, M. K., \& Sudyana, D. (2021). Pelatihan secure computer user untuk meningkatkan kesadaran siswa terhadap keamanan data dan informasi. J-PEMASJurnal Pengabdian Masyarakat, 2(1), 17-24.

Yustanti, W., Qoiriah, A., Bisma, R., \& Prihanto, A. (2019). Strategi identifikasi resiko keamanan informasi dengan Kerangka Kerja ISO 27005: 2018. JIEET (Journal of Information Engineering and Educational Technology), 3(2), 51-56.

Yuwinanto, H. P. (2015). Privasi online dan keamanan data. Palimpsest. 